Archaeological Journal

\title{
The Aucissa Fibulae
}

\section{F. Haverfield M.A., F.S.A., Hon.F.S.A.Scot.}

To cite this article: F. Haverfield M.A., F.S.A., Hon.F.S.A.Scot. (1903) The Aucissa Fibulae, Archaeological Journal, 60:1, 236-246, DOI: 10.1080/00665983.1903.10852942

To link to this article: http://dx.doi.org/10.1080/00665983.1903.10852942

$$
\text { 曲 Published online: } 16 \text { Jul } 2014 .
$$

Submit your article to this journal

LII Article views: 2

Q View related articles $\asymp$ 


\section{THE AUCISSA FIBULAE.}

By F. HAVERFIELD, M.A., F.S.A., Hon.F.S.A.Scot.

The practice of inscribing fibulce with makers' names was probably not very widespread in the Roman world. The recorded instances of fibulae thus marked are few, and though others doubtless exist in public and private collections, ignored and undescribed, these can hardly be numerous enough to swell the total to a great size.

Probably the least rare of these fibulae are those which bear the maker's name Aucissa. ${ }^{1}$ 'They all, so far as is recorded, belong to one and the same type of fibula. It is a simple type, devoid of elaborate devices or complicated ornament, but it possesses definite features. Instead of the usual spiral coil or spring to control the pin, it has (like some other Roman types) a hinge working inside a tiny cylinder, which is so short as hardly to project sideways beyond the breadth of the rest of the object. The name Aucissa is in each case placed just above this cylinder. The pin is straight; the sheath in which its point rests, when it is fastened for use, is plain and small and often terminates in a knob. The bow is roughly semicircular; it is a flat narrowish band of metal, widest near the hinge and decorated only by lines and beading which run along it. Enamelling seems in no case to be used. This type of fibula is not confined to the name Aucissa. It occurs occasionally with other names. It occurs exceedingly often uninscribed, having been found very commonly in many parts of the Roman Empire north of the Mediterranean, and outside it; Almgren quotes an example found as far away as the Government of 'Tomsk in Siberia, and Tischler mentions instances from the Caucasus.

The following is, I believe, a completer list than any yet published, of the specimens marked with the name Aucissa, and it includes two unedited items from Britain $(16,17)$. I have put first in the list those found in

\footnotetext{
1 I assume the commoner form rarex Augissa a variety or an Aucissa to be correct and the error.
} 
Italy or close to it, then those found in Gaul, and lastly those from other places. As several of the specimens are of uncertain or unknown provenance, it is possible that we may in some cases be dealing with duplicate notices of the same object, seen at different times in different dealers' shops.

(1) Found near Rome, in excavations on the Via Nomentana, about 1830, inscribed AVGISSA. Kestner, Bulletino dell' instituto di corrispondenza archeslogica (Rome), 1831, p. 42. He does not say whether the fibula was found associated with objects of any particular date. Hence Dressel, C.I.L. XV. 7096, reading AVGISSA.

(2) Found at Rome in the river Tiber; now in the museum at the Baths of Diocletian. Inscribed AVCISS $\Lambda . \quad$ Dressel, C.I.L. XV. 7096.

(3) Uucertain provenance, but probably found in Rome: seen there in a private collection. Inscribed AVCISS A. Dressel, C.I.L. XV. 7096.

(4) Castel d'Asso, in Etruria. Inscription faint, read as AVGlıiv. Bormann, C.I.L. XI. 6719, 2.

(5) Arezzo (Arretium) in Etruria. Inscription read as VSSDAV but plainly $\Lambda$ VCSS $\Lambda$ like No. 7 . Borman, C.I.L. XI. 6719. 2, from an old MS. source (Codl. Maruc. A, 198, fo. 529).

(6) Found (apparently) near Chiusi in Etruria. Inscribed AVCISSA. Gamurrini, Appendice (Florence, 1880), No. 495: hence Milani, Strena Helbryiana, p. 194 , etc.

(7) Found near Marzabotto, in the A pennines south of Bologna, now in the Marzabotto Museum. Inscribed AVOSSa. G. Gozzadini, Di un' antica necropoli (Bologna, 1865), pp. 31,54 , and plate xvii. 17; Montelius, Civitisation primitive en Italie (Stockholm, 1895), I. fig. 184 , with a cut here reproduced (fig. 1):

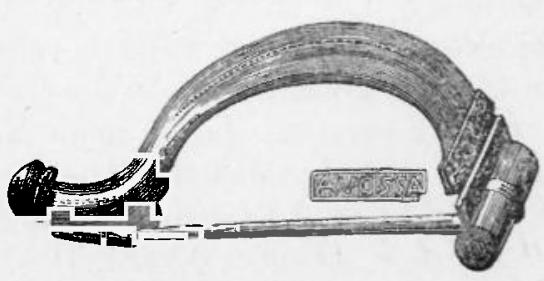

FIG. 1.-FOUND AT MARZaBOtTo, ITALY. (Full size.) hence Almgren, Nordeuropiische Fibelformen, No. 242, Milani (as above); C.I.L. XI. 6719, 2. The remains found at Marzabotto are mainly Etruscan, in some part Gaulish ; 
few appear to be later than the Roman conquest of the district in the third century B.c. But this filula differs widely from the other Marzabotto finds; the actual place of its discovery is not recorded, and Tischler is doubtless right (Gurina, p. 30), in separating it from the remains with which it is usually classed." The reading of the name was at first taken to be aurssa, but aucissa seems to be certain. The $\mathrm{Q}$ is merely CI coalescing, as on Nos. 5, 12, 14 and 16.

(8) Uncertain proverance: seen in a private collection in Naples. Inscribed .. AVCISSA .. . Parascandolo, Cariatidi (Naples, 1817), p. 88, note 139, with cut; hence Milani (as above), Mommsen, C.I.L. X. 8072, 22 . I reproduce the cut from Milani (fig. 2).
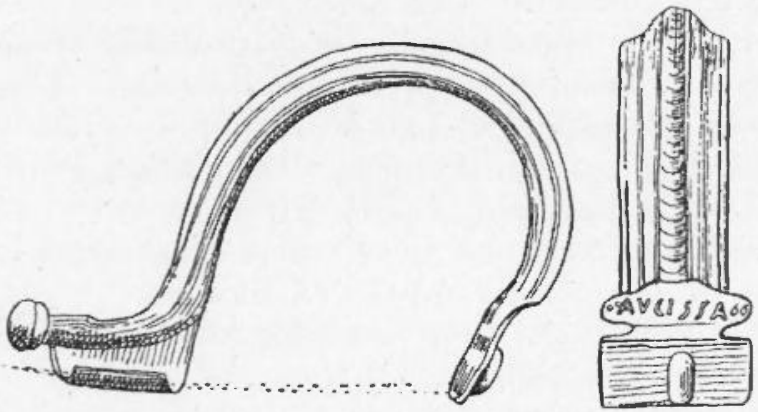

FIG. 2.-FOIND PROBABLY NEAR NAPLES.

(9) Uncertain provenance: seen in a dealer's shop in Florence. Inscribed AVCISSA or AVGISSA. R. Garrucci, Sylloge inscriptionum lat. (Turin, 1877), No. 2272; Bormann, C.I.L. XI. 6719,2 . It is not, however, clear whether these two writers refer, between them, to one, or two, or possibly three fibulae.

(10) Found at Isera, near Nemesino, in North Italy ; now in the Innsbruck Museum. Said to be inscribed AVESSAI or AVGSSAI. H. Pais, Supplementa Italica ad C.I.L.V. (Rome, 1888), 1087, 2 (from Orsi). Plainly Aucissa, misread or imperfect.

1 It is usually asserted that all the Marzabotto finds are pre-Roman, but Gozzadini's plates include a few pieces which are pretty certainly much later.

Ther may have been found separatoly. Tischler's view is accepted by Brizio, Monumenti Antichi, i. (18ऽ9), 330. 
(11) Siscia (Sissek, in Croatia); now in the museum at Vienna. Inscribed $\Lambda$ VCISS $\wedge$ C.I.L. III. 12,031, 2 (from Kubitschek).

(12) Dalheim, near Luxemburg, now in the Trier Museum. Inscribed $\Lambda$ VGSS $\Lambda$ i. F. Hettner, Westdeutsche Zeitschrift, iii. 186 ; A. Riese, Correspondenzblatt, xvi. 136. I am indebted to Dr. E. Krïger for casts of the inscription. The $\mathrm{V}$ is faint; the CI coalesce (or almost so); at the end is an upright stroke of which the top is lost, possibly $\mathrm{F}$ for fecit, possibly ornament. Numerous Roman remains have been found at Dalheim, and among them uninscribed fibulae of the Aucissa type and objects datable to the coinmencement of the Empire: see $P u b$ lications de la soc. pour la recherche . . . dans le grandduche de Luxembourg, ix. (1854), and xi. (1856), p. Ixxi.

(13) Mainz or near it (? Rheinzabern); now in the Mainz Museum, No. 2272. Inscribed III $\Lambda$ VCISS 1. Becker, Römische Inschriften des Museums der Stadt Mainz (Mainz, 1875), p. 113 ; Brambach, 1821, etc. all reading backwards VASDAVIII ; corrected by Riese (as above), and Körber, Inschriften des Mainzer Museums (Mainz, 1900), No. 155, with a cut here reproduced (fig. 3). The three lines at the beginning

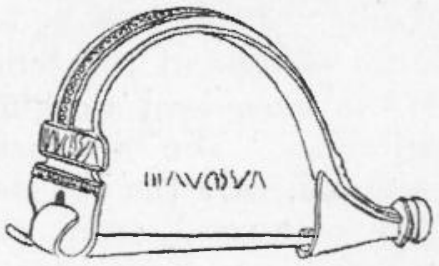

EIG. 3.- FOCND NEAR MAINZ, GERMANY. (Full size.) seem to be rude ornament, with no special meaning; they recur on No. 17.

(14) Uncertain provenance: bought from a dealer at Alzey in Rheinhessen and probably found near that town, now (or recently) in private possession of Dr. Fliedner in Monsheim, near Worms. Inscribed $\cdots \Lambda \operatorname{VGSS} \Lambda \cdots$.
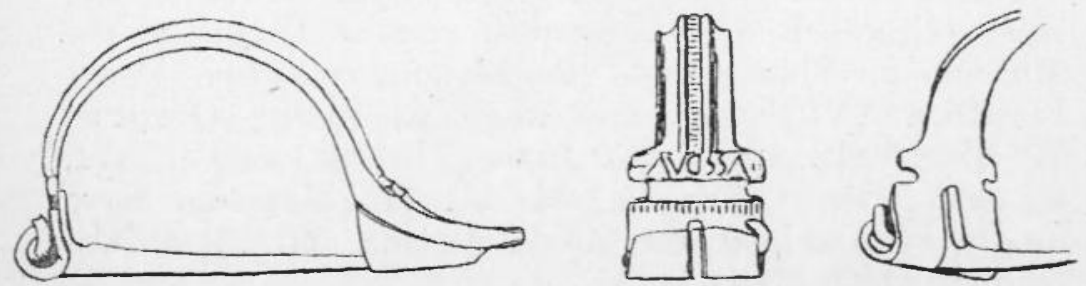

FIG. 4.-FOCND IN RHETNIIISEEN, GERMANY. 
O. Olshausen, Verhandlungen der Berliner Gesellschaft fur Anthropolugie, 1897, p. 286, with cut here reproduced (fig. 4). The pin of this fibulc has a small spur close to the hinge which fits tight against the bow (behind the hinge) when the pin is fastened in its sheath; No. 17 has a similar spur and so have several uninscribed specimens which I bave seen.

(15) Uncertain procenconce: bought from a dealer in Paris in 1875 and now in the St. Germain Museum, No. 22,266. Inscribed AVCISSA. Maxe-Werly, Bulletin de la Societe des Ant. de France, 1883, p. 291 -(figure of the inscribed part), R. Mowat, Bulletin Epigraphique, iii. 273.

(16) Found at Charterhouse-on-Mendip, in Somerset; now in private possession of $\mathrm{Mr}$. A. C. Pass, of Clifton, Bristol. Inscribed $A$ VASS or AVCISS. Unpublished : my copy. I am not sure if the pin is the original one nor whether the CI of the inscription coalesce quite entirely. There is room for an $\mathrm{A}$ at the end, but no sign of it. This and the following item were found about 1875 in some lead workings on the site of the Roman lead mines. The circumstances of their discovery were not noted. Of the objects found at the spot about 1875 a few seem pre-Roman; the rest are Roman of various (lates from about A.D. 49 onwards (fig. 5, upper part).

(17) Same place and history. Inscribed III $\wedge$ VCISS. Unpublished: my copy. There are two doubtful strokes which are faintly indicated in the cut (fig. 5), riz. a fourth stroke before $\Lambda$ and a second before $S$; I think these are probably accidental. There is no space for an $\mathrm{A}$ at the end. The three strokes before $\Lambda$, doubtless mere ornament, recur on No. 13 ; the pin has a spur like that of No. 14.

(18) Found at Hissarlik in the Troad, in the uppermost (Graeco-Roman) stratum; now at Berlin in the Museum fur Volkerkunde (Schliemann collection 6532). Inscribed $\Lambda \mathrm{VCISS} \Lambda$. Olshausen, as above; Götze in W. Döpfeld's Trija and Ilion (Athens 1902) p. 414, fig. 436; Dr. Gotze and Mr. C. H. Blakiston have kindly re-examined the fibula for me and attest the reading which I give.

(19) Found in the Kuban region, in the Western 

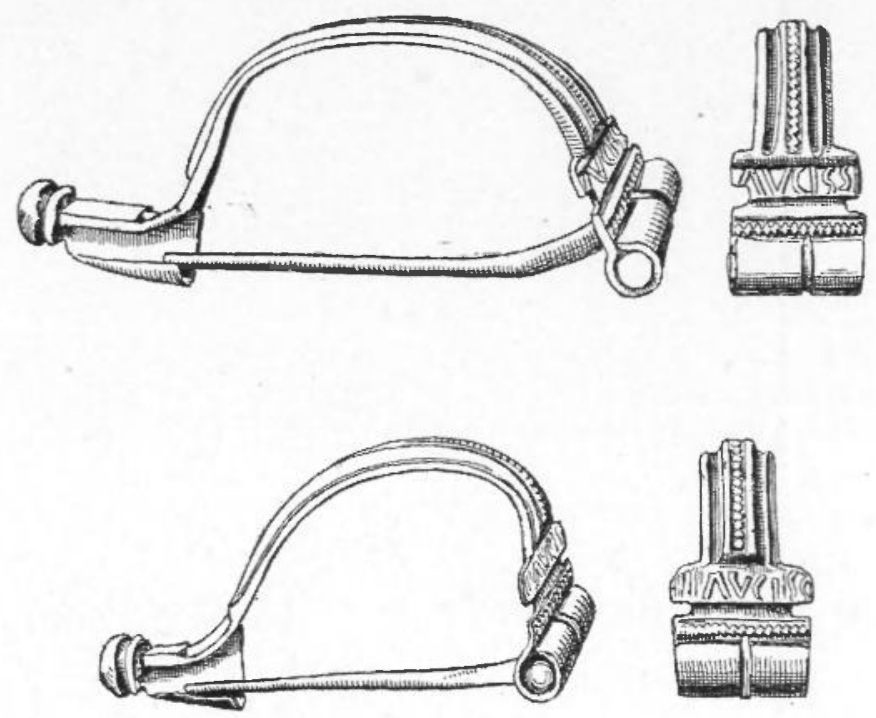

fig. 5.-FibUlae foUNd at charterhouse on MENDIP, NEAR ChEDdar, SOMERSET. (Full size.)

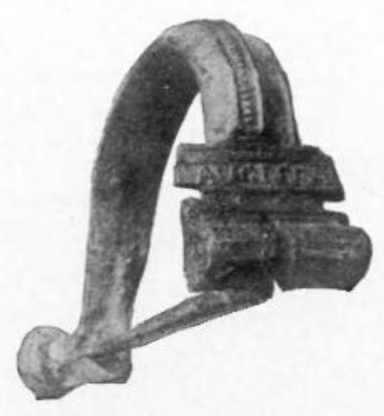

FIG. 6.-PERHAPS FOUND IN ROME. (Full size.) 
Caucasus; now in the Berlin Museum fur Volkerkunde. Inscribed AVGSS:. Olshausen, as above; re-examined for me by Dr. Gotze and Mr. C. H. Blakiston.

(20) Found at Kurtatija in the Caucasus, now in the Berlin Museum fur Volkerkunde. Inscribed AVCISSA. Unpublished: communicated to me by Dr. Gotze and Mr. C. H. Blakiston.

(21) Unknown provenance: now in the Berlin Antiquarium (from Gerhard's collection). Inscribed AV. CISSA according to C. Friederichs, Berlins Antike Bildwerke, ii. (Kleinere Kunst), p. 100, No. 263 ; hence Furtwangler, Olympia, iv. (Bronzen), 183, etc. Dressel, C.I.L. XV. 7096, gives AVGISSA - and suggests that the piece came from Rome. By the kindness of Dr. Pernice, of the Antiquarium, I am able to give an illustration (fig. 6). He tells me that the lettering is really AVCISSA and so it appears on the photograph, and on a cast which he has kindly sent me. But it is a $C$ that is very like a $G$.

Two observations must naturally occur to any reader of this list. In the first place, the records of the finds are throughout so imperfect that they help very little in determining the date of the fibulac. And in the second place, the distribution of the finds is so strange that it leaves us in considerable perplexity as to the place of their original manufacture. Two views have been held on these questions. Italian writers, like Milani, consider the Aucissa fibulae to be Etruscan, or at least EtruscoRoman; they refer them to the third or second century B.C., and explain Aucissa as an Etruscan name. On the other hand, German writers, like Schumacher, Riese, and Ritterling, call them Gaulish, and perhaps eastern Gaulish (Rhenish or Alpine) rather than Gaulish proper, and date them to the beginning of our era and the first century A.D. The available evidence seems on the whole to favour the latter view, but it is conflicting and justifies hesitation.

In the first place, as to the date. The records of the Aucissa fibulae, as I have said, do not help in this matter; none of the twenty-one specimens is known to have been found with objects by which it could be dated. But the uninscribed fibulae of the same type lend some 
light. One, figured by Montelius (plate xiii. fig. 183, whence fig. 7 here) was found at Carru in Piedmont in

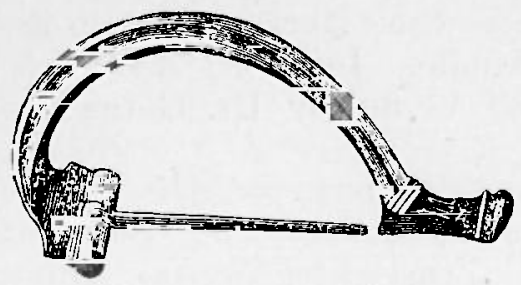

FIG. 7.-FOUND AT CARTU, ITALY.

(Full size.)

a grave with a coin of the Emperor 'Tiberius.' Others have been found at Haltern (perhaps the Roman Aliso) in Germany (fig. 8), at Andernach on the Rhine and at Mont Beuvray in France, on sites which belong to the beginuing of our era and along with datable objects such as coins of Augustus." On the other hand they are rare at Heddernheim (near Frankfurt am Main), a site first occupied about A.D. $80,{ }^{3}$ and they appear not

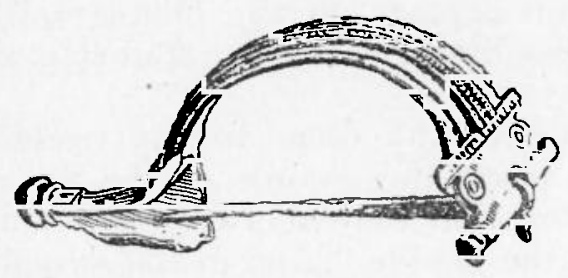

FIG. 8.- HALTERN, GERMANY.

('Three-quarter size.' to occur at all in the forts of the RhenoDanubian Limes, which belong to the second and third centuries of our era.

The few facts that I liave been able to collect about uninscribed Aucissa fibulae in our island tend in the same direction. No specimens seem to have been found in the north, in the region of the two walls, nor at York, nor again at Caerwent: places where the Roman occupation dates, at earliest, flom the later years of the first century. But a specimen has been tound at $\mathrm{Hod}$ Hill, where the remains belong to the first half of the

\footnotetext{
1 Fabretti, Atti della societa d'archeologia per la provincia di Torino ii (1879), pl. IV. fig. 6, cited by Mlaii in Strena Helbigiana, 149.

2 E. Ritterling, Haltern, 116; 0 . Hirschfeld, sitzungsberichte der $\mathrm{kgl}$. preuss. Akademie, 1897, 1103 . See al:o Tischler's article in A. B. Meyer's Gurina, p. 30, and K. Schumacher, Westdeutsches Korrespondenzblatt, 1895, 25-28. Hettner, in his Drei Tempelbezirke im Trevererlande (Trier, 1901), p. 26, cites an example found with a coin of Nero. Bianchetti, Sepolereti di
}

Ornavasso in Atti della socirta di archeologia di Torino, vi. (1895), 224, plate X. 16, eites an example found with a coin of Augustus (B.C, 12). Ghirardini in Notizie degli Scavi, 1883, p. 410 (plate xrii. 13) cites another from Este. I slould add that Milani cites an example with added carving from Populonia and connects it with objects of B.c. $250-150$, but it is not clear that the fibula was actually discorered with those objects.

${ }^{3}$ A. Riese, Mittheilungen iiber romische Funde in Heddernheim, II. 33. 
first century, and at several sites in the south which might be connected with the earlier years of the Roman Conquest. A specimen found near Meols in Cheshire is matched by British coins found at the same place. On the other hand, Mr. Lawson's museum at. Aldborough (Isurium) contains a specimen, and we can hardly place the occupation of Isurium earlier than the latter part of the first century. ${ }^{1}$

These indications of date are in harmony with the general characteristics of the fibulae themselves. We cannot, indeed, decide on our present evidence either the place where or the time when the linge was first adopted in place of the spiral coil for the attachment of the floula pin. But it is a device which belongs to the Roman Empire much more than to the earlier periods in the long history of the fibula, and we can hardly attribute it to so early a date as the second or third century B.c. Again, the ornamentation of the bow of the Aucissa fibulcue, while it finds analogies in other fibulae used during the early Empire, differs considerably from most of the earlier work. ${ }^{2}$

More difficulties arise when we proceed from the question of date to that of place. The distribution of the Aucissa filulae, as I have said, is perplexingly wide and affords no certain clue. ${ }^{3} \quad A$ primr we might argue that bronze objects of the period in question are more likely to have been made in Italy and exported to Gaul, than made in Gaul or on the Rhine and exported to Italy. Instances are. well enough known of bronze work made in Italy, stamped with Italian makers' names and exported to Northern and Western Europe; it may be sufficient in passing to refer to the paterae of the Cipii and Ansii made in Campania. ${ }^{4}$ But instances of export

1 One specimen, in the Ashmolean, is said to hare been found at Gloucester with coins of Tiberius and Antonia Drusi, but the exact facts are doubtful (James. Douglas, Nienia Britannica (London, 1;93). p. 133, plate xxvi).

2 Compare such specimens as those in Bonner Jahrbücher, 101, pl. IV. fig. 4, $5,15,18$. Hildebrand and Montelius both connect the Aucissa type with the Certosa and la Tene group of fibulae (-Antiquarisk Tidskrift for Sverige, vi.
189, viii), but ons wants to limit the field more narrowly than this.

3 Tischler remarks that the wid, distribution of these fibulae suggests export from Italy. But it might equally well be argued that the Danube provides an easy route from eastern Gaul to the Black Sea and the Cancastis.

4 C.I.L. X. 8071, 8072; H. Willers, Die roinischen Bronzeeimer von Hemmoor; Archueological Journal, XLIX. (1892), 228. 
from Gaul into Italy are much harder to find. In agreement with this a priovi probability is the fact that about half the recorded examples of the inscribed "Aucissa" type have been found in Italy, while less than a third can be assigned to Celtic lands, Gaul and Britain. And as Tischler observed, the type of fibula to which the Aucissa specimens belong, is not particularly like any early Celtic type ; though, for that matter, it is not very much more like any early Italian type.

On the other hand, the name Aucissa appears to be Gaulish, or at least Celtic. It has been called Etruscan or Etrusco-Roman, but names in -issa do not occur in Etruscan, ${ }^{1}$ while in Latin they first appear in the Romance period and then only as feminines. On the contrary, they are common, as masculines, in Gaul and in the Celtic lands of Central Europe." The tirst part of the name is also explicable as Celtic, since names beginning with Auc- and Auci- are not uncommon in Gaul, and the whole name, Aucissa, seems to occur on a broken piece of "Samian" found in Paris about a hundred years ago. ${ }^{3}$

Moreover, a Gaulish filula-maker is no novelty. The Gauls are well-known to have been skilful in the manufacture of small metal objects like fibulae, and we can point to definite traces of actual work in fibulae, which constitute a good parallel to Aucissa. Mowat has recorded in the Bulletrn epigraplique about a score of names inscribed on fibulae found in Gaul. 'They are obviously makers' names and, while about half of them are ordinary Roman names, about half of them are Gaulish names, Accu, Atrectos, Boduos,

1 There was in Etruscan a large class of names in -isa, but these seem to be feminine genitives (or the equivalent thereof). It is conceivable that one of these might have been transliterated into a Lalin nominative in -issa, but no instance of such a change seems to exist. I do not think the forms Pabassa, Hunossa, Gargossa, in Pauli's Corpus Inser. Etrusc., 832, 1295 and 1955 , are adequate parallels, as they seem to be Etruscan genitives, not Latin nominatives. For does any such name as *Auc-isa or *Aug-isa seem to occur in Etruscan.

- Holder, Sprachschatz, s.v. -issa ; Indices to C.I.L. 11I. etc.
3 Griraud de la Vincelle, Antiquites gauloises et romaines recueillies dans les jardins du palais du senat (Paris, 1807), pl. VII. fig. 97 , but with no reference to it in the text. The fragment is broken at the beginning and reads nCISSA, but there seems no real doubt that the name is Aucis:a. From Grivaud, Schuermans Sigles, 630; Bulletin epigraphique, II. 120 ; C.I.L. XII. 10010,219 . The object is apparently lost.

4 III. 261; IV. 31, 116, Plates. Compare Bulletin de la Soc. des Antiquaires de France, 1883, 291. 
Carillus, Durnacus, Iovincillus, Iulios Avo, Litugenus, Nertomarus and the like. The fibulae which bear these names vary in character, but some belong to the Aucissa type, as for instance, the fibula of Durnacus, which I here reproduce from M. Mowat's article (fig. 9). Now these names are not only Gaulish, but most of them occur only in Gaul ; they do not belong to any eastern Celtic district in Central Europe. And it is to be added that the whole practice of placing makers' names, whether Gaulish or Roman, on fibulae seems especially Gaulish. That country has yielded the largest number of recorded

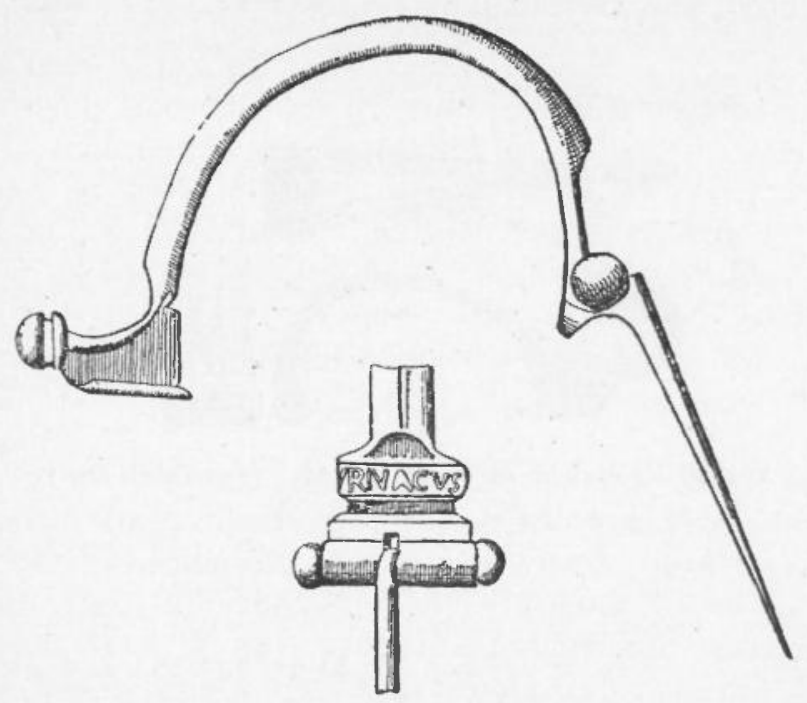

FIG. 9. FOUND AT NAIX, FRANCE.

fibulae thus inscribed. In other provinces the inscribed fibulae are generally of a different kind; they bear such inscriptions as Constanti vivas or utere felix, and they usually belong to a far later date than that which we have assigned to the Aucissa species. ${ }^{1}$ It is possible that we should go on to trace some connexion between the practice of stamping "Samian" ware made in Gaul, and the practice, a much rarer practice, of stamping

1 For example, a silver fibula marked $>$ VTERE FELIX $<$ was found in 1858 at Selce near Djakovo in Slavonin in a grave, along with a lamp, bronze vase, and coins of Constantine and Licinianus, S. Ljubic, Inscriptiones quae Zagrabiae asservantur (Zagrabiae, 1896), 69. 
fibulae made in Gaul. But the Gaulish potters copied an Etruscan fashion, and the Gaulish fibula-makers might have done the same, so that the argument is not much advanced by such a consideration. On the whole, the balance of direct and indirect evidence favours the view that the fibulae stamped with the name Aucissa were made in Gaul, or at least copied from Aucissa fibulcue made in Gaul. It does not follow that the uninscribed fibulae of the same type were Gaulish or that the type had a Gaulish origin. In deciding these questions, caution will be desirable, and until further evidence be discovered, the verdict may he reserved.

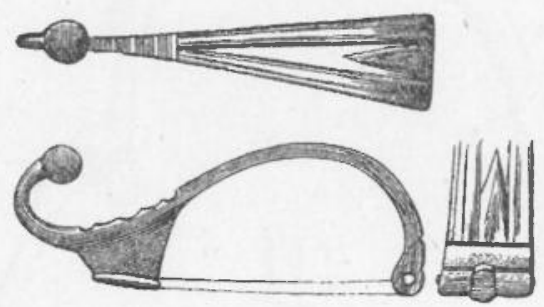

fig. 10.-fotnd Near chidst, italy. (Two-thirds size.) 